\title{
Recenzja książki Marii Bystrzanowskiej, mutyzm wybiórczy. Poradnik dla rodziców, nauczycieli i specjalistów, Oficyna Wydawnicza "Impuls", Kraków 2017, s. 137
}

Książka Marii Bystrzanowskiej Mutyzm wybiórczy. Poradnik dla rodziców, nauczycieli $i$ specjalistów, jest na polskim rynku wydawniczym czwartą (po publikacjach: Anny Herzyk, Afazja i mutyzm dziecięcy: wybrane zagadnienia diagnozy $i$ terapii, Lublin 1992, Wydawnictwo Polska Fundacja Zaburzeń Mowy, s. 38; Anny Skoczek, Mutyzm: zagadnienia teorii i praktyki, Kraków 2015, Akademia Ignatianum, Wydawnictwo WAM, s. 354; Moniki Cabały, Agnieszki Leśniak-Stępień, Renaty Szot, Katarzyny Szyszki, Mutyzm wybiórczy: trzy spojrzenia, Kraków 2016, Oficyna Wydawnicza „Impuls”, s. 48) pozycją poświęconą mutyzmowi wybiórczemu (MW). Książka, jak wskazuje podtytul, jest poradnikiem skierowanym do rodziców, nauczycieli i specjalistów (m.in. logopedów, psychologów, pedagogów, lekarzy pediatrów), napisanym przez praktyka - logopedę z ponad 20-letnim stażem, specjalistę wczesnego wspomagania rozwoju dziecka, od kilku lat zajmującym się wspieraniem osób z mutyzmem wybiórczym i ich rodzin, a także mającym doświadczenie $\mathrm{w}$ prowadzeniu konferencji, szkoleń i warsztatów poświęconych mutyzmowi wybiórczemu.

Książka Marii Bystrzanowskiej składa się ze wstępu (s. 7-9), części poradnikowej, złożonej z sześciu rozdziałów (s. 11-109) oraz podsumowania (s. 111-112). Na s. 113-115 autorka zamieściła dość obszerną bibliografię, głównie angielskojęzyczną. Szkoda jednak, że nie przywołuje wśród pozycji książek polskojęzycznych poświęconych mutyzmowi. Na końcu pracy (s. 117-137) znajduje się aneks z 11 załącznikami. 
We wstępie autorka szczegółowo wyjaśnia, dla kogo przeznaczona jest książka. Wśród jej odbiorców wymienia rodziców, którym trudno na początku jest zaakceptować fakt, że dziecko w rodzinie funkcjonuje normalnie, a po przekroczeniu progu przedszkola czy szkoły milknie. Rodzice często zmagają się również z negatywnymi komentarzami docierającymi $\mathrm{z}$ otoczenia typu: dziecko manipuluje otoczeniem, wybiera sobie osoby do rozmowy, rodzice nie pozwalają mu mówić. Prezentowany poradnik ma pomóc rodzicom zrozumieć istotę zaburzenia, problemy dziecka po to, by wspierać je i pomagać mu w procesie terapii. Odbiorcami monografii mają być również nauczyciele i specjaliści (logopedzi, psychologowie, pedagodzy), którzy powinni mieć wystarczającą wiedzę na temat istoty zaburzenia, a w przypadku specjalistów - także samego przebiegu terapii. Zdobycie wiedzy jest dlatego tak ważne, że do tej pory wiele dzieci z MW pozostaje niezdiagnozowanych, a wśród nauczycieli i specjalistów, co jest przerażające, wciąż można spotkać się z opiniami, iż dziecko autystyczne nie chce mówić. Taką opinię usłyszałam również ostatnio $\mathrm{w}$ trakcie konferencji naukowej od specjalisty $\mathrm{z}$ duży stażem zawodowym i dorobkiem akademickim. Jak pisze autorka we wstępie, treści zawarte $\mathrm{w}$ książce, w przeciwieństwie do obcojęzycznej literatury, głównie angielskojęzycznej, uwzględniają również specyfikę terapii dziecka z MW w polskich warunkach. Bystrzanowska wyraża nadzieję, że po lekturze poradnika rodzice, nauczyciele oraz specjaliści poszerzą nie tylko teoretyczną, ale i praktyczną wiedzę na temat omawianego zaburzenia.

W rozdziale I, pt. Mutyzm wybiórczy - jako zaburzenie w werbalnym komunikowaniu się o podłożu lękowym, autorka przytacza definicje, omawia jego istotę oraz przyczyny. Umiejscawia również mutyzm wybiórczy w Międzynarodowej Statystycznej Klasyfikacji Chorób i Problemów Zdrowotnych ICD-10 oraz w klasyfikacji Amerykańskiego Towarzystwa Psychiatrycznego DSM-V. Zwraca uwagę na fizjologię lęku w mutyzmie wybiórczym, który stanowi zarówno przyczynę, jak i objaw zaburzeń funkcjonowania emocjonalnego. Jak pisze Bystrzanowska: „U osób z MW dochodzi do zapamiętania w korze mózgowej przykrej sytuacji lękowej związanej z niemówieniem. Dziecko kojarzy tę sytuację z miejscem, osobami, objawami i doznaniami. Następnie powiela te sytuacje wielokrotnie i je utrwala" (s. 17). Wymienia i opisuje czynniki mające wpływ na pojawienie się mutyzmu wybiórczego: a) czynnik ryzyka, czyli podtrzymujące: predyspozycje genetyczne, mutyzm wybiórczy w rodzinie, niewłaściwe postępowanie $\mathrm{w}$ stosunku do dzieci wrażliwych, polegające na porówny- 
waniu ich do innych zdolniejszych dzieci, poniżanie dziecka, obniżanie jego wartości, b) czynniki wywołujące MW: utrata kogoś bliskiego, separacja rodziców, zmiana miejsca zamieszkania, narodziny rodzeństwa, poczucie odrzucenia, stawianie dziecku zbyt wysokich wymagań, którym nie jest w stanie sprostać, wielojęzyczność, c) czynniki podtrzymujące: akceptacja niemówienia przez otoczenie, brak zaobserwowania w porę niepokojących objawów, zmuszanie dziecka do mówienia, szantażowanie dziecka, by zaczęło mówić, stosowanie różnych metod terapii na zasadzie „może pomoże", stosowanie komunikacji alternatywnej (s. 19-22). Następnie na podstawie klasyfikacji ICD-10 i DSM-V prezentuje charakterystyczne objawy mutyzmu wybiórczego, zarówno te podstawowe, jak i te, którą mogą mu współtowarzyszyć. Opisuje mutyzm wybiórczy ciężkiego i lekkiego stopnia, przytacza opisy konkretnych przypadków dzieci z tymi dwoma stopniami nasilenia objawów.

$\mathrm{W}$ rozdziale II poświęconym mutyzmowi wybiórczemu i innym współistniejącym zaburzeniom autorka przedstawia wyniki badań własnych dotyczących MW. Na podstawie internetowo przeprowadzonej na Facebooku (mutyzm.org.pl) ankiety, którą wypełniło 100 osób - rodziców dzieci z MW zebrała Bystrzanowska odpowiedzi na pytanie o zaburzenia współistniejące. Wnioski z powyższych badań są następujące: oprócz lęku przed mówieniem i wzmożonym napięciem emocjonalnym występują trudności z jedzeniem w niektórych miejscach, wady wymowy, nadwrażliwość dotykowa (s. 31). Wyniki ankiet potwierdziły większą częstotliwość występowania MW u dziewczynek. Ważne jest też to, że najliczniejszą grupą dzieci z MW w badanej populacji okazały się pięcio-, sześciolatki, czyli dzieci $\mathrm{w}$ wieku obowiązku przedszkolnego. Kolejne podrozdziały poświęcone są następującym kwestiom: mutyzm wybiórczy i fobia społeczna, mutyzm wybiórczy z zaburzenia mowy i języka, mutyzm wybiórczy i wielojęzyczność, mutyzm wybiórczy i zaburzenia za spektrum autyzmu (ASD), mutyzm wybiórczy a nieśmiałość. Bystrzanowska, pomimo istnienia związku między współwystępowaniem MW a lękiem społecznym, zestawia mutyzm i fobię różnicując oba te zaburzenia. Autorka słusznie wnioskuje, że wczesna terapia MW zapobiega pojawieniu się pełnego obrazu fobii społecznej w późniejszym wieku. Jak podkreśla, na skutek braku relacji werbalnych $\mathrm{z}$ rówieśnikami nie dochodzi do nabywania umiejętności komunikacyjnych $\mathrm{w}$ naturalnych sytuacjach, co powoduje wzmożony poziom lęku przed mówieniem u dzieci z mutyzmem. Autorka dalej konstatuje, że "zaburzenia językowe i wady wymowy należą do 
czynników wywołujących i podtrzymujących lęk przed mówieniem, jeśli więc skumuluje się kilka czynników, w tym poważna wada wymowy, wtedy istnieje duże prawdopodobieństwo ujawnienia się MW" (s. 35). W podrozdziale poświęconym MW i autyzmowi podkreśla Bystrzanowska jak ważna jest świadomość objawów obu tych zaburzeń nie tylko wśród nauczycieli przedszkoli czy szkół, ale przede wszystkim wśród diagnostów. Specjaliści w celu postawienia trafnej diagnozy muszą umieć dokonać diagnozy różnicowej tych zaburzeń, biorąc pod uwagę m.in. kwestie wybiórczości mówienia i zachowania dzieci z MW. Trafnie Bystrzanowska dopuszcza u dzieci z łagodną postacią mutyzmu, u których występuje wybiórczość mówienia, postawienie podwójnej diagnozy. Takie rozwiązanie pozwala doprecyzować właściwe strategie terapeutyczne i rokuje, jeśli chodzi o efekty terapii.

W kolejnym, III rozdziale zatytułowanym Sytuacja dziecka z mutyzmem wybiórczym w przedszkolu, szkole i $w$ domu, autorka zwraca uwagę na lękową osobowość dziecka z MW, na dwoistość jego natury, na którą składa się inny sposób funkcjonowanie dziecka $w$ domu (dziecko swobodnie rozmawia, śmieje się, śpiewa, rozrabia), a inny poza nim, np. w przedszkolu czy szkole (tu milczy, brakuje mu energii, jest smutne, cechuje je uboga mimika i mała dynamika ruchów). Bezspornie konstatuje, że dzieci i młodzież z MW wymagają specjalnych potrzeb rozwojowych (SPR) i specjalnych potrzeb edukacyjnych (SPE), ponieważ stwierdza się $u$ nich spektrum objawów utrudniających lub uniemożliwiających funkcjonowanie ruchowe, sensoryczne, poznawcze, emocjonalno-społeczne, psychiczne, a także funkcjonowanie $\mathrm{w}$ zakresie komunikacji. Autorka słusznie zwraca uwage na fakt, że w Polsce rozwiązania prawne dotyczące udzielania pomocy terapeutycznej dzieciom autystycznym są niewystarczające, nie ma jednolitego modelu pracy z takimi osobami, brak jest specjalistów i ośrodków specjalizujących się w terapii MW. Zaznacza, że „szkoły i placówki wspierające rozwój dzieci powinny gwarantować dzieciom z MW wyrównywanie szans edukacyjnych, tak aby mogły w pełni wykorzystać swoje możliwości psychofizyczne i osiągnąć wyniki zgodne ze swoim potencjałem rozwojowym" (s. 46).

W rozdziale IV, Diagnoza - czyli gdzie, kto i jak powinien diagnozować mutyzm wybiórczy, Bystrzanowska apeluje, by nie czekając na formalną diagnozę MW dzieciom podejrzewanym o to zaburzenia zapewnić, wdrożyć działania naprawcze, ale pod pewnymi warunkami: 1) w przedszkolu/szkole musi pracować świadomy w zakresie MW specjalista, który 
otoczy dziecko właściwą terapią, 2) rodzice dziecka powinni być powiadomieni przez specjalistę o podejrzeniu MW oraz powinni otrzymać fachowe wskazówki do pracy $\mathrm{z}$ dzieckiem $\mathrm{w}$ domu, 3) specjalista powinien przeprowadzić szkolenie całego personelu placówki, 4) przedszkole/szkoła powinno stworzyć odpowiednie warunki do pracy z dzieckiem (s. 49). Autorka omawia również $\mathrm{w}$ tym rozdziale dwa arkusze obserwacji do szybkiej oceny podczas względnej diagnozy, stanowiące załączniki 1. i 2. Arkusz te, mające na celu ułatwienie obserwacji dziecka $\mathrm{z}$ podejrzeniem MW niezbędnej do postawienia wstępnej diagnozy pod kątem objawów występujących $\mathrm{w}$ domu, najbliższym środowisku, miejscach publicznych oraz szkole, a także zobrazowanie podstawowych objawów, których znajomość przez nauczyciela jest niezbędna, żeby dostrzec i opisać w opinii sytuację dziecka z podejrzeniem MW w klasie/szkole, mogą również okazać się pomocne w monitorowaniu postępów terapeutycznych. Ich zaletą jest, zdaniem Bystrzanowskiej, to, że są krótkie, zawierają proste pytania, posiadają przystępną instrukcję, wypełnienie ich trwa kilka minut, są przydatne dla rodzica, nauczyciela i specjalisty, istnieje możliwość ich wielokrotnego wykorzystania, jednak, co najważniejsze, ich skuteczność sprawdzono i potwierdzono podczas wielu badań dzieci autystycznych (s. 51). Autorka opisuje kolejność działań w procesie diagnostyczno-terapeutycznym w poradni psychologiczno-pedagogicznej, odsyłając jednocześnie czytelników do załączników 4. i 5. Opis tych działań daje wiedzę rodzicom jak powinno wyglądać badanie psychologiczne, logopedyczne i pedagogiczne dziecka oraz jakie kroki należy przedsięwziąć, by dziecko z MW otrzymało właściwą pomoc terapeutyczną. Bystrzanowska prezentuje również niezwykle przydatny podczas spotkania specjalistów z rodzicami kwestionariusz wywiadu z rodzicami dziecka z trudnościami w komunikacji werbalnej (podejrzenie mutyzmu wybiórczego) (zob. załącznik 6).

Rozdział $\mathrm{V}$ poświęcony terapii dziecka $\mathrm{z}$ mutyzmem wybiórczym przynosi gotowe rozwiązania, ponieważ autorka zwraca $w$ nim uwagę, jak postępować w stosunku do dziecka lękowego. Pisze, iż należy zmodyfikować pewne postawy, zachowania rodziców, jak np. zakazywanie dziecku rozmawiania $\mathrm{z}$ obcymi, pozwalanie na unikanie sytuacji, $\mathrm{w}$ których dziecko ma coś powiedzieć, odpowiadanie za dziecko, okazywanie zdenerwowania niepowodzeniami werbalnymi dziecka, zmuszanie go do mówienia, zbyt entuzjastyczne podchodzenie do sukcesów dziecka z MW, proponowanie nagród $\mathrm{w}$ zamian za mówienie itd. Również postawy nauczycieli należy zmodyfikować (por. np. zmuszanie dziecka do odpowiedzi, akcep- 
tacja niemówienia, ignorowanie dziecka z MW itd.). Na podstawie własnych obserwacji, doświadczeń Bystrzanowska przedstawia funkcjonujące wśród rodziców obiegowe opinie dotyczące terapii dzieci z MW, które nie zawsze są zgodne z prawidłowym podejściem do tego zaburzenia. Udziela wskazówek, rad, jak rodzice powinni z takimi dziećmi postępować. Następnie prezentuje jedną dotychczas najlepszych i najskuteczniejszych terapii dla dzieci z mutyzmem wybiórczym, czyli metodę małych kroków, opierającą się na technikach behawioralnych. Trzy techniki behawioralne pomagają dziecku aktywować mowę. Są to: a) wygaszanie bodźca, poprzez oswajanie dziecka $\mathrm{z}$ miejscem $\mathrm{i}$ osobami $\mathrm{w}$ przedszkolu/szkole, b) modelowanie oraz c) desensytyzacja (odwrażliwianie), z trzema etapami: identyfikacją bodźców wywołujących lęk, ich hierarchizacją i odprężeniem mięśni, czyli relaksacją. W formie tabel (s. 71-72) przedstawia autorka sposoby oddziaływań terapeutycznych w MW, wyodrębniając: a) sposób funkcjonowania dziecka, b) metodę oddziaływania terapeutycznego, c) miejsce oddziaływania, d) osoby zaangażowane $w$ terapię. W omawianym rozdziale $M$. Bystrzanowska prezentuje plan działania terapeutycznego w przedszkolu, szkole, $\mathrm{w}$ domu. Wymienia przykładowe zadania dla zespołu pracującego z dzieckiem autystycznym - dla rodzica, nauczyciela, koordynatora - psychologa, logopedy. Podaje podstawowe zasady pracy terapeutycznej z dzieckiem z MW. Omawia ważne aspekty, które należy uwzględnić w terapii mutyzmu wybiórczego, takie jak: a) obraz MW (postać ciężka, lekka, rozległość strefy niemówienia), b) współistniejące z MW zaburzenia, c) wiek osoby z MW, d) czas trwania zaburzenia, e) możliwość uczestnictwa rodzica $\mathrm{w}$ terapii dziecka $\mathrm{z}$ MW, f) doświadczenia osoby z MW, która mogła być już wcześniej objęta terapią, ale nie przyniosła ona oczekiwanych efektów, g) osoby zaangażowane w terapię. Kolejne kwestie, które autorka podejmuje, to: jak nawiązać dobrą relację z dzieckiem? jakie stopnie osiągnięć komunikacyjnych dziecka z MW udało się Bystrzanowskiej osiągnąć? jaka jest rola $\mathrm{w}$ terapii różnych specjalistów? jakie jest odpowiednie miejsce do prowadzenia terapii? jaki jest przewidywany jej czas? Na podstawie własnych doświadczeń autorka przytacza warunki, które muszą być spełnione, żeby dziecko z MW mogło rozmawiać w dużej grupie. Są to bardzo cenne wskazówki, pomocne nauczycielom i terapeutom. Zwraca uwagę na przyczyny niepowodzeń w terapii, takie jak np. błędnie postawiona diagnoza, niedobra współpraca między terapeutą, nauczycielami i rodzicami, brak wiedzy na temat MW, nieuwzględnienie $\mathrm{w}$ terapii etapu generalizacji mowy, niezapewnienie dziecku $\mathrm{w}$ terapii 
poczucia bezpieczeństwa itp. Autorka przedstawia również opis i analizę przypadku trzyletniej dziewczynki z MW (s. 86-94), w tym: identyfikację problemu, genezę i dynamikę problemu, znaczenie i konsekwencje problemu, prognozę, propozycję rozwiązań, wdrożenie oddziaływań i efekty oddziaływań. Poza tym prezentuje swoją autorską metodę terapii dziecka autystycznego, którą nazywa metodą mowy chóralnej (od chóru do solo, odwrotny sliding in). W formie przejrzystych tabel (s. 97-100) demonstruje przykłady niewłaściwych zachowań w stosunku do dziecka z MW i daje propozycje modyfikacji tych zachowań. Wreszcie odpowiada na najczęstsze pytania stawiane przez rodziców i nauczycieli.

Ostatni, VI rozdział, pt. Prewencja poświęcony jest praktycznym informacjom i poradom na temat tego, na jakie objawy $u$ dziecka powinien zwrócić uwagę nauczyciel w przedszkolu/szkole, w jaki sposób rodzice mogą odpowiednio przygotować dziecko z MW do rozpoczęcia edukacji przedszkolnej, jak psychicznie przygotować dziecko do pójścia do placówki.

W rozdziale podsumowującym autorka podkreśla, że książka nie ma charakteru naukowego, ale przede wszystkim charakter poradnikowy. I tak rzeczywiście jest, bowiem zawiera szereg cennych wskazówek dotyczących diagnozy i terapii mutyzmu wybiórczego. Wiedza, którą Bystrzanowska dzieli się z czytelnikiem, jest efektem jej wieloletniego doświadczenia w pracy z dziećmi autystycznymi. Metody pracy, które poleca były przez nią wielokrotnie skutecznie wykorzystywane w pracy zawodowej.

Świetnie opracowany jest aneks książki, w którym znajduje się jedenaście załączników, które stanowią m.in.: arkusz obserwacji dziecka z podejrzeniem mutyzmu wybiórczego dla rodziców, arkusz obserwacji ucznia z podejrzeniem mutyzmu wybiórczego $\mathrm{w}$ przedszkolu/szkole, mapa mowy dziecka z mutyzmem wybiórczym i plan terapii, procedury badania w poradni psychologiczno-pedagogicznej, kwestionariusz wywiadu z rodzicami dziecka $\mathrm{z}$ trudnościami w komunikacji werbalnej (podejrzenie mutyzmu wybiórczego), zalecenia dla nauczyciela dziecka z zespołem Aspergera i mutyzmem wybiórczym, zadania dla dziecka z mutyzmem wybiórczym z uwzględnieniem obciążenia komunikacyjnego, przykładowa drabina z zadaniami dla dziecka z mutyzmem wybiórczym. Są tu gotowe do badań arkusze, z których chętnie skorzysta każdy specjalista.

Książka napisana jest przystępnym językiem, materiał w niej zaprezentowany jest przejrzysty, usystematyzowany, poparty fragmentami wypowiedzi pacjentów, ich rodziców, fragmentami tekstów z blogów, z Face- 
booka. Pozycja wzbudza zachwyt rodziców i specjalistów, którzy na forach internetowych podkreślają, że jest to fantastyczny przewodnik, który poprowadzi za rękę rodziców oraz specjalistów (logopedów, psychologów, pedagogów, nauczycieli) od diagnozy po terapię.

Taką pozycję warto przeczytać, warto ją mieć też w swojej biblioteczce. 